\title{
PENGANGKAT BARANG PADA KONDISI BANJIR BERBASIS RASPBERRY PI MELALUI TWITTER SEBAGAI OUTPUT MEDIA INFORMASI
}

\author{
Ferry Sudarto ${ }^{1}$ \\ Eka Purwandari ${ }^{2}$ \\ Aldien Sora Andrea ${ }^{3}$ \\ Email:ferry.sudarto@ raharja.info, eka@ raharja.info, aldien@ raharja.info
}

\begin{abstract}
Appointment of goods is essential in the operation of the company. Currently forklift with manual or automatic that has not been working efficiently. Especially forklift in flood conditions. So we need tools that work the forklift automatically on flood conditions, the process of appointment, and notify the results of such appointments by personal message via the output of media-based Raspberry Pi Twitter. The circuit uses a forklift Soil Moisture Sensor is used to detect water in the vicinity of the sensor. Raspberry Pi will process the input and give orders to the Motor Servo work to move the hinge table so the table is automatically lifted. Lifting these goods become important in minimizing damage to properties affected by flooding. So as to improve the efficiency of lifting equipment goods in flood conditions. If the Soil Moisture Sensor exposed to water it will automatically give the data to the Raspberry Pi and processed into information. Once processed, the Raspberry Pi will give two orders to Twitter as output information and the Servo Motor as the physical output will move. The process that is done it does not take long, after the sensor is exposed to water, the appliance works with a period of about 1-2 minutes. Then the items on the table would be safe to avoid flooding with automatic.
\end{abstract}

Keywords : Flood, Goods Support, Raspberry Pi, Motor Servo.

\begin{abstract}
ABSTRAK
Pengangkatan barang merupakan hal yang penting dalam operasi perusahaan. Saat ini pengangkat barang dengan cara manual ataupun yang sudah otomatis belum bekerja dengan efisien.Terutama pengangkat barang dalam kondisi banjir. Maka dibutuhkan alat pengangkat barang yang bekerja secara otomatis pada kondisi banjir, melakukan proses pengangkatan, dan memberitahukan hasil pengangkatan tersebut dengan output berupa Personal Message melalui Media Twitter berbasis Raspberry Pi. Rangkaian pengangkat barang ini menggunakan Soil Moisture Sensor yang digunakan untuk mendeteksi air di sekitar sensor. Raspberry Pi akan memproses input dan memberi perintah ke Motor Servo bekerja untuk menggerakan engsel meja sehingga meja secara otomatis mengangkat. Pengangkat barang ini menjadi hal penting dalam meminamilisir kerusakan barang yang terkena banjir. Sehingga dapat meningkatkan efisiensi alat pengangkat barang pada kondisi banjir. Jika Soil Moisture Sensor terkena air maka otomatis akan memberi data menuju Raspberry Pi dan diolah menjadi suatu informasi. Setelah diproses maka Raspberry Pi yang akan memberi 2 perintah kepada Twitter sebagai output informasi dan kepada Motor Servo sebagai output fisik yang akan bergerak. Proses yang dilakukan alat ini tidak memakan waktu lama, setelah sensor terkena air maka alat bekerja dengan kurun waktu sekitar 1 - 2 menit. Kemudian barang yang ada di atas meja akan aman terhindar banjir dengan otomatis.
\end{abstract}

Kata Kunci: Banjir, Pengangkat Barang, Raspberry Pi, Motor Servo. 


\section{PENDAHULUAN}

\section{Latar Belakang}

Secara geografis, wilayah Indonesia yang terletak pada garis ekuator dan diapit oleh dua samudera yang menyebabkan wilayah Indonesia beriklim tropis sehingga cenderung memiliki intensitas curah hujan yang tinggi. Oleh karena itu wilayah Indonesia memiliki resiko tinggi akan terjadi bencana alam, khususnya bencana bencana banjir. Hal ini disebabkan oleh banyak hal, mulai dari kondisi alam sampai kesalahan manusia terhadap alam dan lingkungan. Bencana Banjir yang terjadi secara tiba-tiba bukanlah masalah baru tetapi merupakan masalah besar karena sudah terjadi sejak lama dan pada beberapa tahun terakhir ini mulai merambah ke tengah kota. Dampak yang ditimbulkan banjir pun tidaklah sedikit, banjir dapat merusak lingkungan hidup berupa rusaknya areal pemukiman masyarakat, rusaknya areal pertanian, terhambatnya transportasi, bahkan menghambat kegiatan operasional pada industri. Meskipun sudah berulangkali banjir ditanggulangi dengan berbagai cara, banjir tetap saja datang melanda dan kembali menimbulkan dampak-dampak negatif tersebut.

Banjir yang terjadi secara tiba-tiba misalnya pada saat orang-orang tidur lelap pada malam hari lalu karena adanya hujan yang terjadi semalaman dengan curah hujan yang tinggi biasanya tanpa disadari banjir sudah merendam barang-barang penting yang posisinya diletakan pada keadaan rendah. Hal ini disebabkan tidak adanya kesempatan untuk menyelamatkan barang-barang yang ada pada posisi keadaan rendah karena kondisi yang sedang tertidur lelap. Sehingga dapat menimbulkan kerugian financial yang cukup besar.

Dengan adanya perkembangan teknologi yang pesat pada saat ini masalah-masalah yang timbul karena adanya bencana alam seperti banjir bisa diantisipasi dengan adanya penelitian ini. Penelitian ini ditujukan untuk mengantisipasi dan memperkecil kerugian yang ditimbulkan oleh bencana alam banjir dengan menciptakan suatu alat yang mampu menghindari kerusakan pada barang-barang dengan posisi keadaan yang rendah.

\section{TUJUAN DAN MANFAAT}

a. Tujuan

1. Prototipe yang dapat mengamankan dan mengangkat suatu barang yang akan terkena banjir.

2. Membuat suatu mekanisme pengontrolan prototipe pengamanan dan pengangkatan barang yang dapat bekerja secara baik.

3. Mampu memberikan pemberitahuan ke sosial media yaitu twitter.

4. Menyelesaikan masalah yang ada di lingkungan masyarakat yang rawan terkena banjir.

5. Merancang sistem kontrol pada twitter untuk mengirimkan sebuah pemberitahuan ke twitter, bahwa barang sudah aman dari banjir.

b. Manfaat

1. Mempermudah dalam melakukan kegiatan mengangkat suatu barang ketempat yang lebih aman ketika terjadi banjir.

2. Meringakan proses pekerjaan di bidang industri dan mampu membantu untuk menggantikan tugas manusia yang berhubungan dengan tugas fisik seperti mengangkat barang pada kondisi banjir.

3. Untuk pengoperasian pengangkat barang ketempat yang aman pada saat terkena banjir, dan tidak perlu lagi mengeluarkan tenaga yang berat dalam pengangkatan barangbarang yang akan terkena banjir.

\section{PERMASALAHAN}

Sudah saatnya teknologi berperan dan dimanfaatkan secara optimal dalam membantu mengurangi kerusakan atau kerugian yang disebabkan oleh bencana alam.Terlebih bencana banjir yang sering melanda pemukiman dataran rendah. 
Dalam hal ini banjir dapat merusak segala barang-barang yang ada pada keadaan rendah yang tidak sempat diselamatkan. Untuk mengatasi masalah diatas, maka diperlukanlah konsep dan mekanisme otomatis untuk menyelamatkan barang-barang yang akan terendam banjir dengan cara membuat sebuah meja yang dapat terangkat ketika sensor mengenai air.

\section{RUMUSAN MASALAH}

Dalam rumusan masalah ini memuat uraian secara rinci dari permasalahan yang diidentifikasi pada permasalahan di atas, adapun rumusan masalah dalam penyusunan penelitian ini sebagai berikut:

1. Bagaimana merancang dan membangun meja yang mampu mengamankan dan mengangkat barang-barang yang akan terkena banjir?

2. Bagaimana cara mengkoneksikan meja dengan sosial media dalam mewujudkan fungsinya sebagai output dari kerja alat?

\section{PEMECAHAN MASALAH}

Untuk mengatasi berbagai masalah diatas, maka diperlukan suatu proses yaitu dengan melakukan suatu penelitian yang bertujuan untuk menyelesaikan masalah-masalah yang ada, berikut adalah alternatif pemecahan masalahnya: Dengan adanya penelitian ini ditujukan untuk mengurangi kerusakankerusakan yang terjadi saat masalah datang. Ketika banjir datang sistem ini akan secara otomatis mengangkat barangbarang atau berkas-berkas yang akan terkena banjir. Sehingga tidak perlu membutuhkan banyak waktu dan tenaga yang terbuang. Dan tidak menimbulakn kerugian financial.

\section{LANDASAN TEORI}

\section{a. Raspberry Pi}

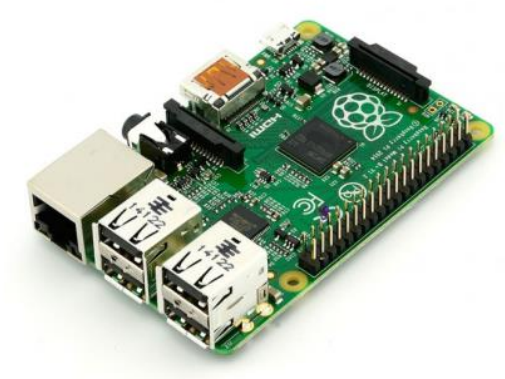

Gambar 1. Raspberry Pi

According to Richardson and Wallace, "The Raspberry Piis a credit sized computer that plug into your TV and a keyboard. It is a capable little computer which can be used in electronics projects, and for many things that your desktop PC does, like spreadsheets,word-processing and games. It also plays high definiton video. "is:pi

Menurut Richardson dan Wallace, ("Raspberry Pi adalah sebuah komputer berukuran sebesar kartu kredit yang terhubung ke televisi dan sebuah keyboard. Komputer kecil ini bisa digunakan untuk proyek-proyek elektronik dan hal lainnya yang bisa dilakukan oleh desktop komputer seperti sebagai mesin pengolah kata, games dan perangkat ini juga mampu memainkan video beresolusi tinggi").

\section{b. Putty}

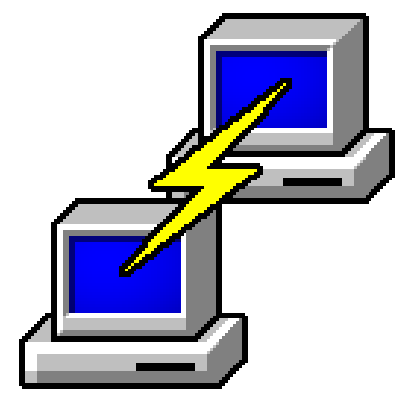

Gambar 2. Logo Putty

Putty adalah sebuah aplikasi open source atau aplikasi gratis sebagai terminal emulator yang dapat bertindak sebagai klien untuk mengakses $\mathrm{SSH}$, 
telnet dan protokol TCP. Putty hanyalah salah satu software yang bisa digunakan pada sistem operasi Windows untuk mengakses sebuah VPS (virtual private server) yang berbasiskan linux.

\section{c. Twitter}

\section{twitter}

Gambar 3. Logo Twitter

Twitter adalah sebuah situs web yang dimiliki dan dioperasikan oleh Twitter Inc., yang menawarkan jejaring sosial berupa mikroblog sehingga memungkinkan penggunanya untuk mengirim dan membaca pesan yang disebut kicauan (tweets). Kicauan adalah teks tulisan hingga 140 karakter yang ditampilkan pada halaman profil pengguna. Twitter adalah jejaring sosial dan micro-blogging, yang memfasilitasi sebagai pengguna, dapat memberikan update (perbaruan) informasi tentang diri pribadi, bisnis, dan lain sebagainya.

\section{d. Motor Servo}

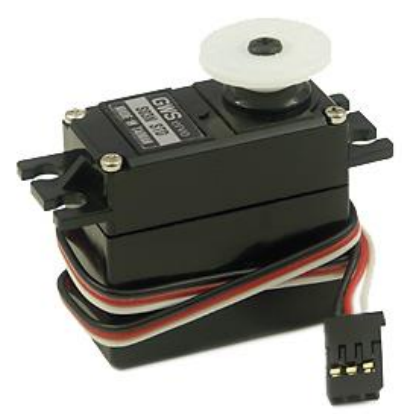

Gambar 4. Motor Servo

Motor servo adalah sebuah motor DC yang dilengkapi rangkaian kendali dengan sistem closed feedback yang terintegrasi dalam motor tersebut. Pada motor servo posisi putaran sumbu (axis) dari motor akan diinformasikan kembali ke rangkaian kontrol yang ada di dalam motor servo. Motor servo disusun dari sebuah motor DC, gearbox, variabel resistor (VR) atau potensiometer dan rangkaian kontrol. Potensiometer berfungsi untuk menentukan batas maksimum putaran sumbu (axis) motor servo. Sedangkan sudut dari sumbu motor servo diatur berdasarkan lebar pulsa yang pada pin kontrol motor servo.

\section{e. Soil Moisture Sensor}

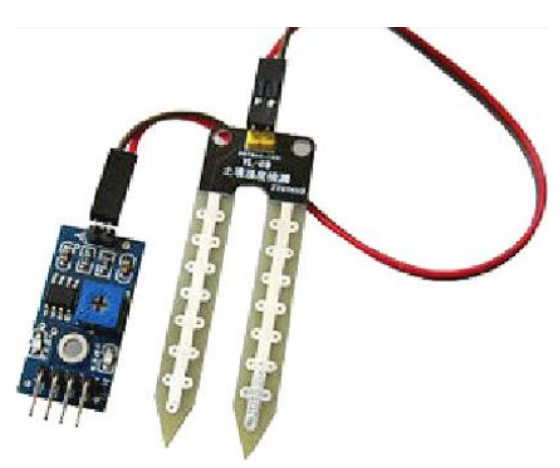

Gambar 5. Soil Moisture

Sensor

Soil moisture sensor merupakan sensor yang mampu mendeteksi intensitas air di dalam tanah. Sensor ini berupa dua buah paku konduktor berbahan logam yang sangat sensitif terhadap muatan listrik. Kedua paku ini merupakan media yang akan menghantarkan tegangan analog yang nilainya relatif kecil. Tegangan ini nantinya akan diubah menjadi tegangan digital untuk diproses ke dalam mikrokontroller.

Soil moisture sensor menggunakan LM393 chip Power supply: $3.3 \mathrm{~V}$ atau $5 \mathrm{~V}$. Sensor ini terdiri dua probe untuk melewatkan arus melalui tanah, kemudian membaca resistansinya untuk mendapatkan nilai tingkat kelembaban. Semakin banyak air membuat tanah lebih mudah menghantarkan listrik (resistansi kecil), sedangkan tanah yang kering sangat sulit menghantarkan listrik (resistansi besar).

\section{LITERATURE REVIEW}




Banyak penelitian $\begin{array}{r}\text { yang } \\ \text { dilakukan mengenai }\end{array}$
sebelumnya secara online
penerimaan mahasiswa baru sean
dan penelitian lain yang berkaitan. Dalam
upaya mengembangkan ran
menyempurnakan penerimaan mahasiswa
baru secara online ini perlu dilakukan
studi pustaka (literature review) sebagai
salah satu dari penerapan metode
penelitian yang akan dilakukan.
Diantaranya yaitu:

1. Penelitian ini dilakukan oleh Juliansah dari Sekolah Tinggi Manajemen Dan Ilmu Komputer (STMIK) RAHARJA, Pada Laporan Skripsi tahun 2014 yang berjudul "PERANCANGAN SISTEM KONTROL ROBOT PEMINDAH BARANG MENGGUNAKAN APLIKASI ANDROID BERBASIS ARDUINO UNO". Penelitian ini membahas tentang pemindah barang dengan pengontrolan melalui aplikasi android, hal ini dikarenakan sistem informasi penilaian yg berjalan belum terkomputerisasi. Dengan adanya hal tersebut maka diperlukan suatu sistem untuk memudahkan dan mempercepat keluar masuknya informasi. ${ }^{[1]}$

2. Penelitian ini dilakukan oleh Irawan dari Politeknik Negeri Semarang, Pada Laporan Skripsi tahun yang berjudul "RANCANG BANGUN ROBOT PEMINDAH BARANG DENGAN SISTEM KONTROL BERBASIS MIKROKONTROLER". Penelitian ini membahas tentang rancang bangun robot pemindah barang dengan sistem kontrol berbasis mikrokontroller, hal ini dikarenakan sebagai simulator suatu bentuk sistem mekatronika, dan memberikan gambaran umum tentang mekanisme mekatronika baik dari aspek mekanis, elektrik maupun program yang digunakan. Dengan adanya hal tersebut maka robot pemindah barang ini berhasil menjalankan semua fungsi robot manual, sesuai aturan Kontes Robot Indonesia (KRI) 2011. ${ }^{[2]}$

3. Penelitian ini dilakukan oleh Fajriansyah[34] dari Insitut Teknologi Nasional Bandung, Pada Laporan Skripsi tahun yang berjudul "ROBOT BERODA PEMINDAH BARANG
DENGAN CAPIT BERBASIS

ATMEGA16". Penelitian ini membahas tentang robot yang memiliki kecepatan dan akurasi yang cukup untuk memindahkan barang dari satu tempat ke tempat yang lain, hal ini dikarenakan keduanya harus sinkron pada perancangannya menggunakan dua perangkat yaitu perangkat keras (Hardware) dan perangkat lunak (Software). Dengan adanya hal tersebut maka diperlukan perancangan robot dengan menggabungkan antara ilmu mekanik dengan elektronika. ${ }^{[3]}$

4. Penelitian ini dilakukan oleh Kurniawan dari Insitut Teknologi Sepuluh Nopember Surabaya (ITS), Pada Laporan Tugas Akhir (TA) tahun yang berjudul "RANCANG BANGUN LENGAN ROBOT SISTEM PNEUMATIC UNTUK PEMINDAH BARANG SECARA OTOMATIS". Penelitian ini membahas tentang, hal ini dikarenakan sistem informasi penilaian yg berjalan belum terkomputerisasi. Dengan adanya hal tersebut maka diperlukan suatu sistem untuk memudahkan dan mempercepat keluar masuknya informasi. ${ }^{[4]}$

5. Penelitian ini dilakukan oleh Mohamad dari Universitas Gunadarma, Pada Laporan Skripsi tahun yang berjudul "ROBOT PEMINDAH BARANG BERBASIS LINE FOLLOWER". Penelitian ini membahas tentang robot pemindah barang yang berfungsi sebagai alat bantu manusia untul memindahkan barang-barang berat dengan lebih mudah dan tidak menghabiskan tenaga. Berat barangbarang yang hanya bisa dipindahkan harus kurang dari $10 \mathrm{~kg}$, hal ini dikarenakan robot tersebut masih berbentuk prototipe. Dengan adanya hal tersebut maka harus diperlukan motor yang memiliki kekuatan torsi yang lebih besar guna untuk dapat mengangkat barang lebih besar dan lebih berat. ${ }^{[5]}$

Dari kelima literature review yang ada, telah banyak penelitian mengenai robot pemindah barang. Namun dapat disimpulkan pula bahwa belum ada peneliti yang secara khusus membahas 
atau mengatasi masalah mengenai sistem pengangkatan barang pada kondisi banjir secara otomatis melalui twitter sebagai media informasi dari hasil kerja alat tersebut.

\section{METODE PENELITIAN}

Metode pengembangan sistem yangdigunakan oleh penulis adalah modelprototype jenis I. Prototype memberikan idebagi pembuat maupun pemakai potensialtentang cara sistem akan berfungsi dalambentuk lengkapnya. Adapun langkah-langkahpada model prototype jenis I sebagaimanayang dikemukakan oleh Raymond McLeod Jr. adalah sebagai berikut:

\section{Mengidentifikasikan kebutuhan} pemakai

Analis sistem mewawancarai pemakaiuntuk mendapatkan gagasan dari apa yangdiinginkan pemakai terhadap sistem.

\section{Mengembangkan Prototype}

Analis sistem mungkin bekerjasamadengan spesialis informasi lain,menggunakan satu atau lebih peralatanprototype untuk mengembangkan sebuahprototype.

3. Menentukan apakah prototype dapatditerima

Analis mendidik pemakai dalampenggunaan prototype dan memberikankesempatan kepada pemakai untukmembiasakan diri dengan sistem, tahappengujian.

\section{Menggunakan prototype}

Prototype ini menjadi sistem yangdapat di operasionalkan, tahap implementasisistem.

Untuk lebih jelasnya dapat dilihat pada gambar pengembangan prototype jenis I, berikut ini:

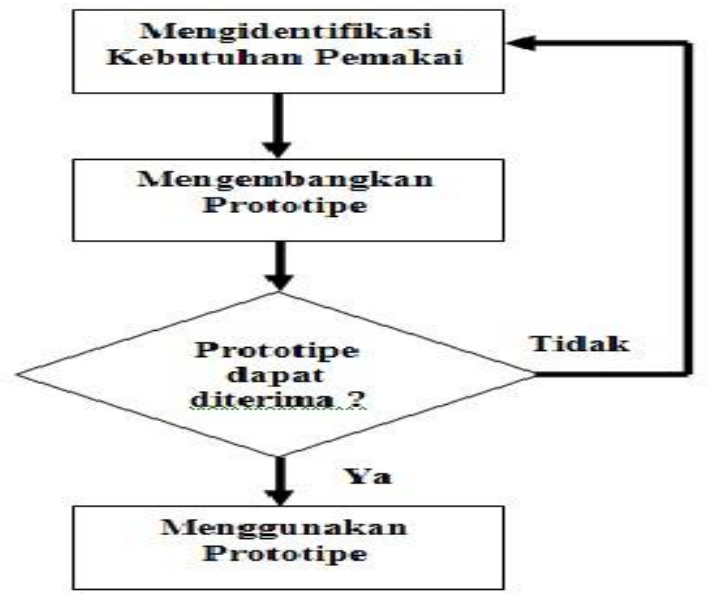

Gambar 6. Pengembagan prototyping jenis 1

(Raymond McLeod Jr. (2001 : 151)

\section{PERANCANGAN BLOK DIAGRAM}

Perancangan blok diagram untuk memperingkas gabungan antara masukan dan keluaran dari suatu model yang akan dibuat.

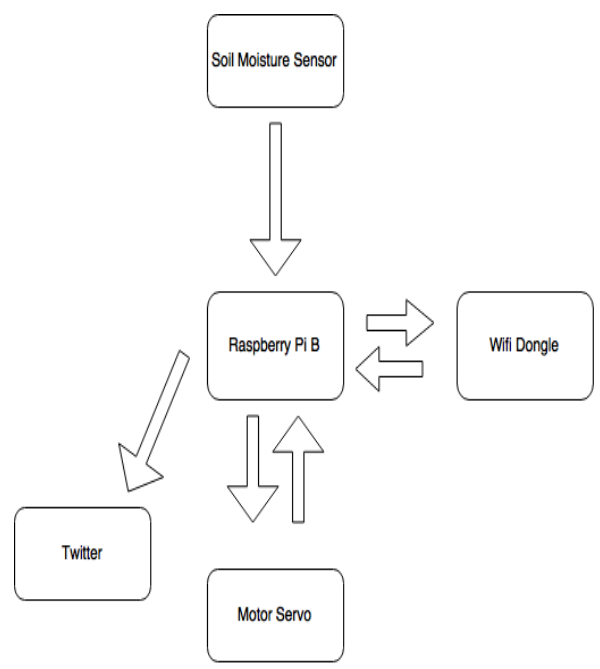

Gambar 7. Perancangan Blok Diagram Pengangkat Barang Pada Kondisi Banjir 


\section{PEMBAHASAN}

\section{DIAGRAM BLOK}

Pada umumnya sistem pengendalian praktis terdiri dari banyak komponen. Maka untuk menyederhanakan dalam menganalisa dipakai Blok Diagram. Dimana tiap-tiap komponen digambarkan oleh sebuah kotak yang mempunyai input danoutput, sedangkan didalamnya dituliskan bentuk transfer fungtion dan komponennya. Pada komunikasi antar komputer, sistem komunikasi antar Twitter dan Raspberry Pi. Alat pengangkat barang memiliki identitas masing-masing. Seperangkat identitas ini meliputi IP (Internet Protokol). Subnet Mask dan juga Token Twitter. Agar mudah dipahami maka penulis membuat diagram blok dan alur kerjanya.

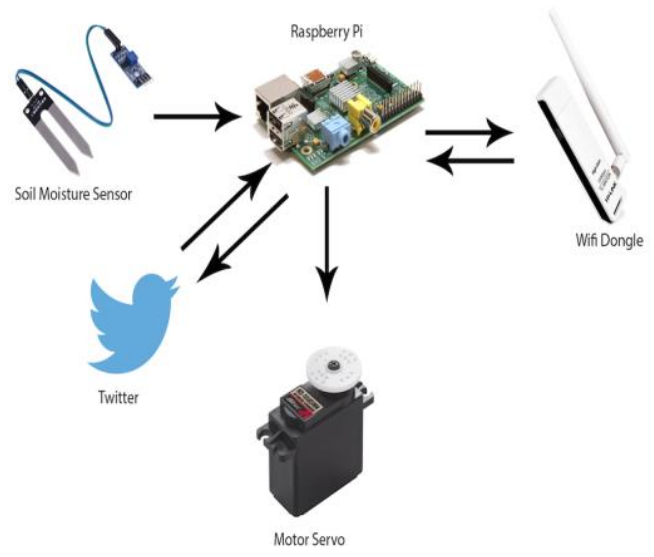

Gambar 8. Diagram Blok Pengangkat Barang Pada Kondisi Banjir

Keterangan dan penjelasan diagram blok sistem diatas adalah sebagai berikut:

1. Soil Moisture Sensor sebagai input pendeteksi adanya air.

2. Raspberry $\mathrm{Pi}$ merupakan perangkat yang digunakan untuk menjalankan aplikasi atau perintah program.

3. TP Link sebagai penangkap sinyal dan mengirimkan informasi kepada Twitter.

4. Twitter sebagai media output informasi yang dikirim oleh Raspberry Pi melalui TP Link.

5. Motor Servo merupakan sebagai penggerak engsel meja.

\section{CARA KERJA ALAT}

Bentuk perancangan fisik alat berasal dari material akrilik. Pada perancangan di bawah ini, sudah bisa dilihat bahwa alat dirangkai untuk menunjang dan mengangkat barangbarang, sehigga barang yang seharusnya terkena banjir, bisa diselamatkan oleh alat.

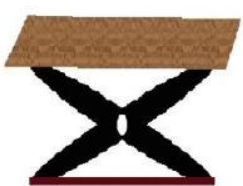

Yeja Dalam Keadaan Normal

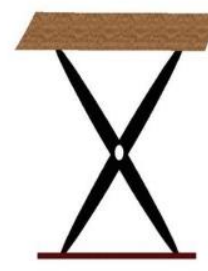

Meja Ketika Sudah Bekerja dan Melalui Proses
Gambar 9. Perancangan Fisik Alat

\section{INPUT}

Pada penelitian ini memakai satu soil moisture sensor sebagai alat input, yang berfungsi untuk mendeteksi tingkat kelembaban tanah. Karena Soil Moisture Sensor berfungsi mendeteksi kelembaban tanah, Soil Moisture Sensor dapat menentukan apakah ada kandungan air di sekitar sensor. Ketika ada air mengenai sensor, maka Soil Moisture Sensor akan mengirim perintah ke Raspberry $\mathrm{Pi}$ sebagai input.

\section{PROCESS}

Setelah itu Raspberry Pi B yang sudah otomatis terhubung dengan wireless and wifi dongle, akan memanggil IP Soil Moisture Sensor dan mengolah data yang diberikan, lalu memerintahkan Motor Servo sehingga Motor Servo bergerak. Proses akan berjalan hanya dalam waktu beberapa menit.

\section{OUTPUT}

Setelah terjadi input dan proses pada alat, maka output sudah dapat dihasilkan. Yaitu, Motor Servo yang bergerak akan 
mengangkat meja lebih tinggi dari ketinggian air banjir yang dideteksi oleh Soil Moisture Sensor. Sehingga barangbarang perusahaan yang penting akan terselamatkan oleh alat secara otomatis. Lalu setelah kondisi barang aman, Raspberry Pi mengolah data kembali setelah Motor Servo berhenti bergerak. Kemudian terakhir, Raspberry Pi yang terhubung dengan wifi dongle akan mengirim informasi berupa status pada twitter yang berisi pemberitahuan bahwa air banjir telah mengenai soil moisture sensor sebagai outputnya.

\section{FLOWCHART SISTEM}

Pada pembuatan sebuah kontrol diperlukan sebuah gambar yang akan menjelaskan alur atau langkah-langkah dari sebuah kerja sistem yang dibuat, sehingga dapat memberikan penjelasan dalam bentuk gambar. Penjelasan yang berupa gambar proses kerja sebuah sistem merupakan gambar dari sistem yang akan dibuat. Tujuan dari pembuatan flowchart adalah untuk mempermudah pembaca dan pembuat sistem itu sendiri untuk memahami langkah-langkah serta cara kerja sebuah sistem yang dibuat. Dari penelitian yang dilakukan menghasilkan flowchart sebagai berikut:

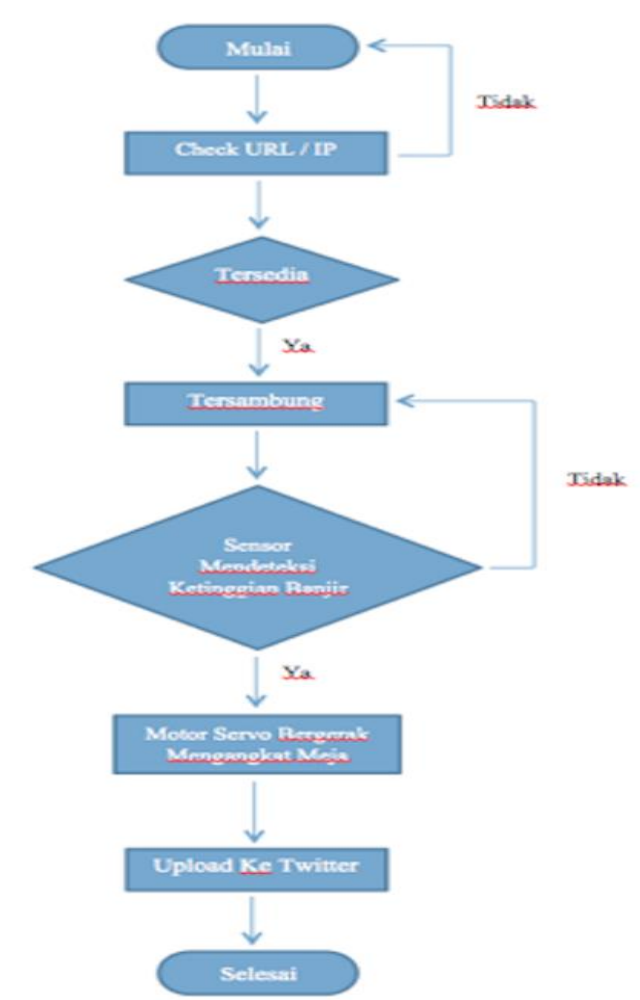

Gambar 10.

Flowchart Sistem

\section{IMPLEMENTASI}

\section{a. Perangkat Keras (Hardware)}

Dalam perancangan perangkat keras ini dibutuhkan beberapa komponen elektronika device penunjang agar sistem dapat berjalan dengan baik sesuai dengan fungsinya. Dalam perancangan perangkat keras ini, alat dan bahan yang dibutuhkan adalah :

1. Personal Computer (PC)

2. Memori SD Card

3. Raspberry Pi B

4. Soil Moisture Sensor

5. TP-LINK WN722N

6. Kabel Jumper

7. Motor Servo

8. Batterai

9. Meja

\section{b. Perangkat Lunak (Software)}

Langkah-langkah dalam installasi perangkat lunak adalah sebagai berikut :

1. Software Raspbian menggunakan Win32 Disk Imager 


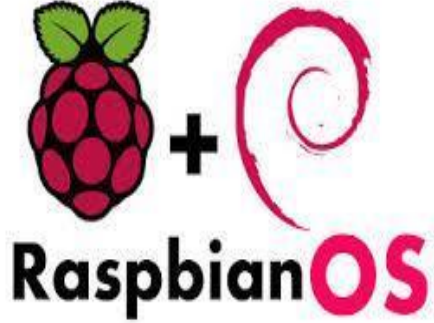

Gambar 11. Logo Rasbian

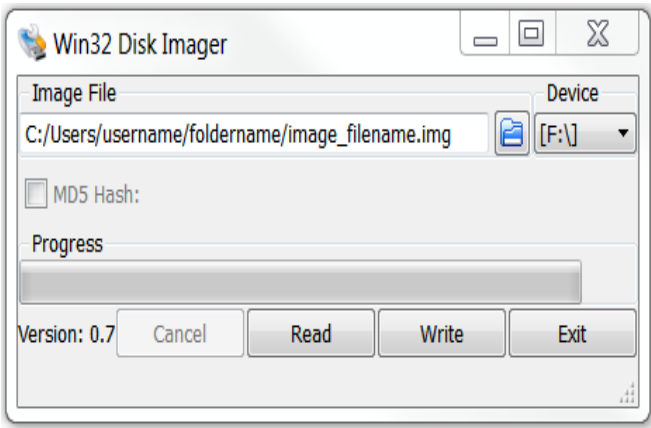

Gambar 12. Logo Win32 Disk Imager

Raspbian adalah sistem operasi berbasis Debian (Linux) yang dapat digunakan pada Raspberry Pi.Raspbian tersebut merupakan seperangkat program dasar dan utilitas yang membuat Raspberry Pi berjalan.Dibutuhkan Software Win32 Disk Imager untuk menginstal Raspbian yang berektensi img. Win 32 Disk Imager merupakan sebuah aplikasi free yang memiliki antar muka, dan berfungsi sebagai writing image pada SD Card

2. Software Python

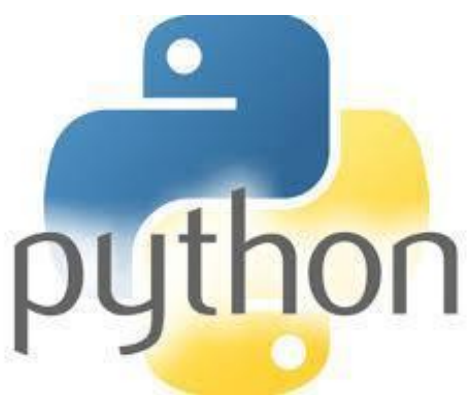

\section{Gambar 13. Logo Python}

Perangkat lunak yang digunakan adalah Python.Phyton adalah salah satu bahasa program, lebih tepatnya interpreter. Dalam dunia pemrograman dikenal dua jenis tipe bahasa program: Compiler dan Interpreter. Compi ler bekerja dengan cara mengubah kode dari bahasa program yang kita buat ke dalam bahasa yang lebih sederhana yang bisa dipahami oleh mesin. Sedangkan Interpreter, dari kode yang kita buat akan diterjemahkan per-perintah.

\section{Software Putty}

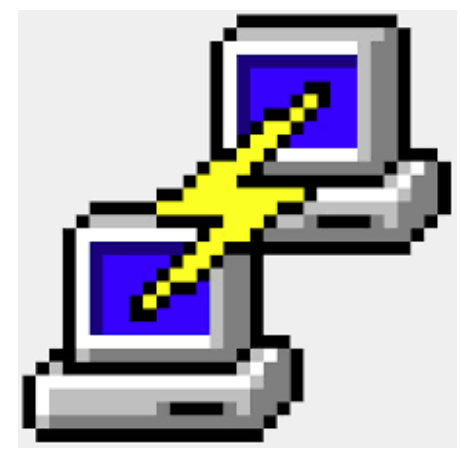

Gambar 14. Logo Putty

Putty adalah sebuah program open source yang dapat Anda gunakan untuk melakukan protokol jaringan SSH, Telnet dan Rlogin. Protokol ini dapat digunakan untuk menjalankan sesi remote pada sebuah komputer melalui sebuah jaringan, baik itu LAN, maupun internet. Program ini banyak digunakan oleh para pengguna komputer tingkat menengah ke atas, yang biasanya digunakan untuk menyambungkan, mensimulasi, atau mencoba berbagai hal yang terkait dengan jaringan.

\section{LANGKAH-LANGKAH INSTALLASI SISTEM}

\section{Installasi Software Raspbian menggunakan Win32 Disk Imager}

$>$ Download image terbaru dari Raspbian Wheezy di alamat berikut http://www.raspberrypi.or g/downloads/

$>$ Pada halaman download, cari RASPBIAN Debian Wheezy dan copy download link pada tombol Download ZIP

$>$ Buka terminal Ubuntu dengan shortcut CTRL + ALT + T 
$>$ Ketik pada terminal sudo apt-get install wget $-y \quad \& \&$ wget (paste link download CTR+SHIFT+V)

$>$ Tunggu proses Download selesai, kemudian colokan SD Card ke laptop / card reader

$>$ Cari alamat SD Card dengan mengetik sudo fdisk -l kemudian akan muncul daftar dari Disk pada laptop. Hati-hati dalam tahap ini, cari alamat SD Card yang diawali dengan mmcblk. Biasanya akan beralamat di /dev/mmcblk0.

$>$ Setelah selesai mengunduh, lakukan cloning ke SD card dengan perintah: sudo dd if=./alamat_dari_file_img of $=/$ dev/nama_sdcard $\quad$ bs $=5 \mathrm{M}$ Contoh : sudo dd if=./2014-1224-wheezy-raspbian.img of $=/$ dev/mmcblk0 bs=5M

$>$ Tunggu hingga proses selesai, setelah itu colokan ke Raspberry SDCardnya, nyalakan dan mulai lakukan penyetingan. Masuk menggunakan akun default username: pi , password: raspberry

Pertama, setting partisi ke mode full dengan cara: sudo raspiconfig

$>$ Cari Expand File System > Yes > Reboot

$>$ Reboot, dan Login kembali, ketik startx untuk masuk ke Desktop.

\section{Installasi Software Python}

Melakukan eksekusi file installer python-2.7.5.msi,

sehingga akan menghasilkan folder Python (kondisi default) di C:/Python27.

$>$ Melakukan pengaturan Environment Variables untuk atribut PATH. Isikanvariable value $>$ C:IPython27〉; $:$ :Pytho n27 Scriptsl.

Membuka Terminal (Command Prompt) Windows, kemudian ketikkan

perintah"python" kemudian klik Enter. Jika instalasi berhasil, tampilan Command Prompt akan masuk ke mode environment Python (lihat gambar di bawah). Untuk menutup modeenvironment Python dapat digunakan perintah exit().

$>$ Coba ketikkan perintah: print "Python is a powerful language".

\section{Installasi Software PuTTy}

$>$ Eksekusi instaler PuTTy atau jalankan dengan mengklik dua kali pada icon PuTTy.

> Isi kolom-kolom yang diperlukan seperti hostname / IP, SSH port dan settingan lainnya yang dirasa perlu seperti auto username login, line buffer dan Simpan settingan tersebut.

> Setelah itu klik open, atau klik dua kali pada nama settingan yang telah Anda simpan.

$>$ Apabila muncul kotak dialog, maka klik "yes".

$>$ Kemudian selanjutnya maka akan tampil layar console, silahkan apabila Anda sudah men-setting auto data login ( dalam contoh diatas adalah "root") maka Anda cukup memasukan passwordnya saja langsung, apabila tidak maka, bapak harus memasukan username Anda terlebih dahulu.

\section{HASIL OUTPUT TWITTER}

Berikut adalah hasil output dari kerja alat yang mana sensor telah mengenai air, maka secara otomatis akan terhubung melalui twitter yaitu sebuah pemberitahuan berupa tweet. Dan setelah sensor mengenai air dan pemberitahuan berjalan secara otomatis, begitu pun motor servo bekerja dengan otomatis yaitu mengangkat suatu meja yg telah dibuat dalam prototipe yang ada. 


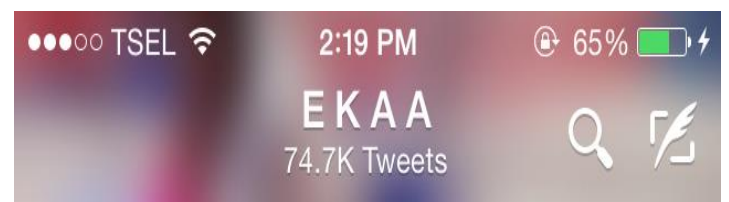

Tweets

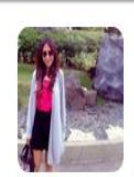

E K A A @ekaaaPR

@ekaaapr ruang kantor banjir pada jam18:23:46

E K A A @ekaaaPR

@ekaaapr ruang kantor banjir pada jam18:20:19

E K A A @ekaaaPR

12/20/14

@ekaaapr ruang kantor banjir pada jam18:11:42

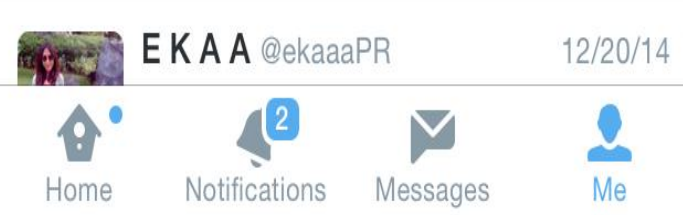

Gambar 15. Tweet Pemberitahuan Banjir

\section{KESIMPULAN}

Hasil penelitian ini diharapkan dapat bermanfaat oleh seluruh masyarakat luas, terutama yang memiliki tempat tinggal di daerah yang rawan akan terkena banjir sebagai suatu teknologi yang berupa prototipe pengangkat barang-barang pada kondisi banjir. Selain itu dapat memberikan informasi yang akurat dan $u p$ to date melalui jejaring social media yaitu Twitter.Berdasarkan hasil dari perumusan masalah penilitian ini dapat di ambil kesimpulan antara lain :
1. Dalam pengangkatan barang-barang yang akan terkena banjir awalnya masih bersifat manual, tetapi dengan adanya prototipe pengangkat barang ini maka dapat dilakukan dengan cepat dan efisien.

2. Tidak lagi membutuhkan banyak tenaga untuk mengangkat barangbarang yang akan terkena banjir tersebut.

3. Memperkecil kerugian financial yang mungkin akan terjadi ketika banjir dating secara tiba-tiba dan dapat merusak barang-barang yang berada pada kondisi rendah.

\section{DAFTAR PUSTAKA}

1. Juliansah, Reza Amar. 2014. "Perancangan Sistem Kontrol Robot Pemindah Barang Menggunakan Apliksi Android Berbasis Arduino UNO". Perguruan Tinggi Raharja, Tangerang, Indonesia

2. Irawan, Bingar Pudyastowo. 2012. "Rancang Bangun Robot Pemindah Barang Dengan Sistem Kontrol Berbasis Mikrokontroler". Politeknik Negeri Semarang, Semarang, Indonesia

3. Fajriansyah, Burhan. 2013. "Robot Beroda Pemindah Barang DenganCapit Berbasis ATMEGA16". Insitut Teknologi Nasional, Bandung, Indonesia

4. Kurniawan, Aditya. 2010. "Rancang Bangun Lengan Robot Sistem PNEUMATIC Untuk Pemindah Barang Secara Otomatis". Insitut Teknologi Sepuluh Nopember, Surabaya, Indonesia

5. Mohamad, Aldy. 2013. "Robot Pemindah Barang Berbasis Line Follower". Universitas Gunadarma, Indonesia

6. Raspberry Pi. What is a raspberry pi. 2014. "Raspberry Pi Foundation UK Registered Charity 1129409". Diambil dari: raspberrypi.org (Tanggal akses 27 April 2015) 
7. Putra, Ikhsan Prakasa. "Download Console PuTTy". 2015 (Tanggal akses 02 Mei 2015)

8. Supriadi, Salman Agus. 2012. "Dasar-dasar Python" (Tanggal akses 03 Mei 2015)

9. Miarana. 2015. [Ulasan \& Cara Install]."6 Sistem Operasi Resmi Yang Dapat Digunakan Untuk Raspberry Pi" (Tanggal akses 03 Mei 2015)

10. Aditya Rizki. Memasang Python pada Windows 7. 2013(Tanggal akses 16 Mei 2015).

11. Belajar Hosting Server. 2013. "Instalasi \& Konfigurasi serta cara menggunakan Putty (SSH)" (Tanggal akses 16 Mei 2015)

12. MiaranaDIY. [TutorialPemula]."Cara Install OS Raspbian Pada Raspberry Pi Menggunakan Ubuntu”. 2015 (Tanggal akses 16 Mei 2015)

13. Fathur, Rahman Danish. 2014. "Apa Itu Putty" (Tanggal akses 16 Mei 2015) 